\title{
QUANTIFICATION OF Staphylococcus aureus AND Escherichia coli FROM BOVINE SUBCLINICAL MILK SAMPLES BY CONVENTIONAL PCR
}

\author{
K. M. Chandrashekar ${ }^{1}$, Shrikrishna Isloor ${ }^{2 *}$, D. Rathnamma ${ }^{2}$, B.M. Veeregowda ${ }^{2}$, \\ Raveendra Hegde ${ }^{3}$, R. Sharada ${ }^{1}$, G. S. Naveen Kumar ${ }^{4}$, Nagendra R. Hegde ${ }^{5}$
}

\footnotetext{
${ }^{1}$ Department of Microbiology, Veterinary College, KVAFSU, Hassan, Karnataka 573202.

${ }^{2}$ Department of Microbiology, Veterinary College, KVAFSU, Hebbal, Bangalore, Karnataka 560024.

${ }^{3}$ Institute of Animal Health and Veterinary Biologicals, Hebbal, Bangalore

${ }^{4}$ Department of Animal Genetics and Breeding, Veterinary College, KVAFSU, Hassan, Karnataka 573202.

${ }^{5}$ ELLA foundation, Genome Valley, Turkapally, Hyderabad, Telangana 500078.
}

Received - April 30, 2018; Revision - August 13, 2018; Accepted - September 25, 2018

Available Online - October 5, 2018

DOI: http://dx.doi.org/10.18006/2018.6(5).808.815

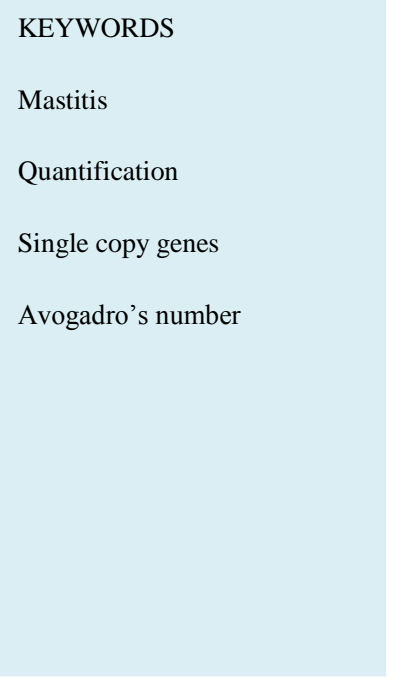

\begin{abstract}
The present study explores the application of conventional PCR and Mole v/s Avogadro's number using single copy genes of Staphylococcus aureus and Escherichia coli for assessing bacterial load in milk samples from mastitis cases. The nuc and uidA genes produced the lowest detection limit for Staph. aureus and E. coli respectively. The present findings estimated that, as few as 60 and 89 genome copies or organisms of Staph. aureus and E. coli were detected, respectively. Based on the LOD of molecules, standard graphs for these genes were generated and this knowledge was applied to milk samples from the field. Spiking known amount of genomic DNA (which in turn indicates organisms based on Avogadro's number) in LB broth and pasteurized milk was carried out to compare the input with output and simulating field conditions. A total of 90 samples from subclinical cases of mastitis were collected from four organized farms located at various villages. Out of 90 samples, 29 (32.22\%) were showed culture and duplex PCR positive. Of these, $12(13.33 \%)$ were found to be positive for $E$. coli alone, nine $(10 \%)$ were found to be positive for Staph. aureus alone, and eight $(8.88 \%)$ carried a mixed infection for both. In conclusion, this study suggests that quantification of bacteria directly from milk by the conventional PCR can be an alternative to time consuming conventional culture method and expensive real-time PCR, but requires extensive standardization.
\end{abstract}

* Corresponding author

E-mail: kisloor@gmail.com (Shrikrishna Isloor)

Peer review under responsibility of Journal of Experimental Biology and Agricultural Sciences.

Production and Hosting by Horizon Publisher India [HPI] (http://www.horizonpublisherindia.in/).

All rights reserved.
All the article published by Journal of Experimental Biology and Agricultural Sciences is licensed under a Creative Commons Attribution-NonCommercial 4.0 International License Based on a work at www.jebas.org.

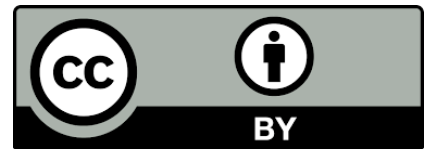




\section{Introduction}

Mastitis continues to be the most important economical in modern dairy industry affecting the quality of milk, milk production, farm economics, and animal welfare. Subclinical mastitis (SCM) is considered as the main form of mastitis in modern dairy herds, affecting 20 per cent to 50 per cent of cows in given herds (Pitkala et al., 2004; Birhanu et al., 2017). In bovines, disease is most frequently caused by microbial infection, commonly associated with Staphylococcus aureus (Staph. aureus) and Escherichia coli (E. coli) which are causative agents of contagious and environmental mastitis, respectively. Detection of SCM is based on conventional tests like Somatic cell count (SCC), California mastitis test (CMT), Electrical conductivity (EC) and Bromothymol blue test (BTB) Whereas, these tests are qualitative, indirectly reflect the infection without exact etiological agent and complicated to interpret, and do not truly indicate the severity of infection (Preethirani et al., 2015). Estimation of the bacterial load could enable us to understand the severity of infection.

Currently employed techniques for quantification of bacteria are plate count method and most-probable-number (MPN) method (Pascual \& Calderon 2000). The disadvantage of plate count technique is negative culture (Phuektes et al., 2001) and timeconsuming (Hogan et al., 1999) whereas MPN is also laborious and time-consuming (Pascual \& Calderon 2000).

Considering the limitations with special reference to longer time, manpower, and cost ineffectiveness associated with the above mentioned techniques, the use of DNA-based assays has become popular recently. The Polymerase Chain Reaction (PCR), which is highly sensitive, specific and so far have been reported only for the qualitative detection or identification of bacteria at earlier stages of infection, but application to gauge the bacterial load which inturn indicates the severity of the infection are lacking. However, real-time PCR can be used to quantify bacterial DNA and thus has potential for accurate enumeration of microorganisms, but high cost is a limiting factor for its wide applicability.

In the present study, the concept of Mole v/s Avogadro's number is explored for quantitative estimation of Staph. aureus and E. coli in bovine subclinical milk samples by conventional PCR assay. Avogadro's number is the number of elementary units such as atoms, molecules or ions in one mole of a substance. Here single copy genes, nuc for Staph. aureus and uidA for E. coli were selected based on its minimum detection limit as mentioned by Chandrashekar et al. (2015).

\section{Materials and Methods}

\subsection{Standardization of duplex PCR}

\subsubsection{Strains and genomic DNA}

Reference cultures of Staph. aureus (Accession No. JN247783) (MTCC No. 96) and E. coli (Accession No. JF926686), were obtained from Microbial Type Culture Collection, Chandigarh, India. The genomic DNA from reference strains were extracted from Staph. aureus and E. coli bacteria using the AMpurE Bacterial gDNA Mini Spin kit (Amnion Biosciences Pvt. Ltd., Bangalore), as per the manufacturer's recommendations. Whereas, genomic DNA from the neat and diluted field milk samples were extracted by using Cremonesi method (Cremonesi et al., 2006). The purity and concentration of the genomic DNA was estimated by using nanodrop spectrophotometer (Thermo Scientific, U.S.A.)

\subsubsection{Duplex PCR}

Five $\mu \mathrm{l}$ of the extracted genomic DNA from the standard reference strains were subjected to PCR containing $2.5 \mu 1$ of $10 \mathrm{X}$ Taq Pol Assay Buffer, $0.5 \mu \mathrm{l}(3 \mathrm{U} / \mu \mathrm{l})$ of Taq Polymerase, $1.0 \mu \mathrm{l}$ $(10 \mathrm{mM} / \mu \mathrm{l})$ of $\mathrm{dNTP}$ mix (i.e., $2.5 \mathrm{mM}$ of each of the four dNTPs), $0.5 \mu \mathrm{l}(10$ picomoles / $\mu \mathrm{l})$ of each of the forward and reverse primers, in a final volume of $25 \mu 1$ (Chern et al., 2011; Hegde et al., 2013). The primers and cycling conditions are detailed in Table 1. Amplification was performed for 30 cycles in all cases. The amplified products $(15 \mu \mathrm{l})$ were subjected to electrophoresis in 2\% agarose gel stained with ethidium bromide, and visualized and documented by using automatic gel doc system (Gel Doc XR; Bio-Rad., U.S.A). The above procedure was applied for the genomic DNA extracted from field milk samples.

Table 1 Primers and cycling conditions used to amplify the single copy genes of Staph. aureus and E. coli for duplex PCR

\begin{tabular}{|c|c|c|c|c|}
\hline Gene & $\begin{array}{l}\text { Primer sequence } 5 `-3^{`} \\
\text { (Forward, Reverse) }\end{array}$ & Cycling conditions & Amplicon (bp) & Reference \\
\hline пис & $\begin{array}{l}\text { GTGCTGGCATATGTATGGCAATTGT } \\
\text { TACGCCGTTATCTGTTTGTGATGC }\end{array}$ & \multirow{2}{*}{$\begin{array}{c}94^{0} \mathrm{C} \text { for } 10 \mathrm{~min} \\
94^{0} \mathrm{C} / 30 \mathrm{sec} \\
57^{\circ} \mathrm{C} / 30 \mathrm{sec} \\
72^{0} \mathrm{C} / 30 \mathrm{sec} \\
72^{0} \mathrm{C} \text { for } 10 \mathrm{~min}\end{array}$} & 181 & Hegde et al., 2013 \\
\hline $\operatorname{uid} \mathrm{A}$ & $\begin{array}{l}\text { ATCACCGTGGTGACGCATGTCGC } \\
\text { CACCACGATGCCATGTTCATCTGCC }\end{array}$ & & 486 & Chern et al., 2011 \\
\hline
\end{tabular}

Journal of Experimental Biology and Agricultural Sciences http://www.jebas.org 


\subsection{Sample collection}

A total of ninety milk samples were collected from four organized farms (Farm A, B, C and D) and various villages (Doddamandiganahalli, Bittagowdanahalli, Kudrugundi, Aladahalli, Rachenahalli, Doddapura, Cheeranahalli, Guddenahalli) in and around Hassan based on CMT. Milk samples were collected in $10 \mathrm{~mL}$ sterile tubes following strict aseptic measures and immediately transported to the laboratory in refrigerated condition and processed for SCC.

Forty samples which having high SCC (> 5,00,000 cells / $\mathrm{mL}$ of milk) (Table 2) were log diluted in LB broth, $100 \mu$ from each dilution was plated on MSA (Staph. aureus) and MCA (E. coli) and genomic DNA was extracted from the rest of the remaining dilutions by Cremonesi method and quantified as above (Cremonesi et al., 2006). Duplex PCR for single copy genes of Staph. aureus (nuc) and E. coli (uidA) was carried out. Quantification of bacterial load in the milk samples were estimated based on the concentration, amplicon size and size of the genomic DNA (assuming Staph. aureus and E. coli to contain 2.81 Mbp and 4.68 Mbp long genomes) by using the Avogadro`s number, formula as follows (Hein et al., 2001; Taponen et al., 2009).

Weight in Dalton $($ gram $/ \mathrm{mol})=($ base pair size of DNA) $\mathrm{X}(330$ Dalton / nucleotide X 2 nucleotides / base pair)

Copy number $=$ grams $/$ molecule $=\frac{\text { gram } / \text { mole }}{\text { Avogadro's }}$ Avogadro's number (i.e. $6.02214199 \times 10^{23}$ )

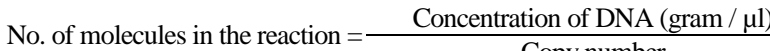
Copy number

\section{Results}

Out of 90 , forty ( 44.44 per cent) and fifty ( 55.55 per cent) samples were found to be positive and negative respectively for subclinical mastitis based on SCC. Among these 40 positive samples, 29 (72.5 per cent) samples were found to be positive for Staph. aureus and E. coli by duplex PCR. Of these, 12 (41.38 per cent) were found to be positive for E. coli alone, nine (31.03 per cent) were found positive for Staph. aureus alone, and eight (27.59 per cent) carried a mixed infection of E. coli and Staph. aureus. Expected amplicon sizes of 181 bp and 468 bp were observed for nuc and uidA genes of Staph. aureus and E. coli, respectively in reference strains (Figure 1) and in all 40 field samples which were positive for SCM by SCC, here we have shown only three samples representing infection of Staph. aureus (Figure 2), E. coli (Figure 3) and mixed infection of both organisms (Figure 4). Bacterial load of Staph. aureus and E. coli in subclinical positive field milk samples were estimated based on the concentration of extracted genomic DNA from milk samples (Table 2).

\section{Discussion and Conclusion}

Subclinical mastitis, which is defined as mastitis that cannot be diagnosed by clinical examination, instead relying on the analysis of inflammatory products in the milk (Ceron-Munoz et al., 2002; Schukken et al., 2003). In most cases, direct or indirect measurement of the milk SCC is used to diagnose SCM. This is often combined with bacteriological examination of the milk to arrive at an etiological diagnosis.

The detection of bacterial etiology is primarily based on conventional isolation and characterization. Routine quantification of organisms according to International Standardization Organization and International Dairy Federation methods (Anonymous, 1995a; Anonymous, 1995b; Anonymous, 1997) apply conventional microbiological technique such as the plate count method based on the use of selective media for direct enumeration or the recovery of isolates after enrichment in selective broth for $24-48 \mathrm{~h}$ at $37^{\circ} \mathrm{C}$. This technique requires up to 6 days for quantification and detection, thus being timeconsuming. In addition, culture-based assays can only enumerate viable organisms in a sample that can be cultured under laboratory conditions. Other methods for quantification include mostprobable-number (MPN), a rather laborious and time-consuming procedure (Pascual \& Calderon, 2000), and the quantification of the enzymatic activity of the bacterial phosphatase (Fang, 1996), which is not specific and can therefore be applied only to pure cultures.

Considering that the above approaches are time-consuming and can produce ambiguous results for species-level identification, PCR has been developed recently for rapid and precise identification of predominant mastitis causing bacteria, especially for Staph. aureus, E. coli and Streptococcus species (Jayarao et al., 1996; Forsman et al., 1997; Kim et al., 2001; Riffon et al., 2001; Daly et al., 2002; Meiri-Bendek et al., 2002; Phuektes et al., 2001; Phuektes et al., 2003; Shome et al., 2011; Sundareshan et al., 2012; Nithinprabhu et al., 2013; Hegde et al., 2013; Preethirani et al., 2015). Whereas these PCR-based approaches have so far been reported for the qualitative detection of bacteria, additional estimation of bacterial load could be of a more practical significance. Currently, enumerating bacteria in mastitic milk is being accomplished by culture-based methods to determine the colony forming units (Hogan et al., 1999). Recently, real-time PCR was developed for rapid enumeration of bacterial load (Koskinen et al., 2010; Gaibani et al., 2013). Other PCR-based methods such as hybridization can also improve the sensitivity of 
Table 2 Details of the samples Viz SCC, Positive by culture and duplex PCR, Quantification based on plating and concentration of genomic DNA

\begin{tabular}{|c|c|c|c|c|c|}
\hline $\begin{array}{l}\text { Sl. } \\
\text { No. }\end{array}$ & $\begin{array}{l}\text { Sample } \\
\text { No. }\end{array}$ & $\mathrm{SCC} / \mathrm{ml}$ & $\begin{array}{l}\text { Results based on culture } \\
\text { and duplex PCR }\end{array}$ & $\begin{array}{l}\text { Quantification based on Culturing } \\
\text { (CFUs } / \mathrm{ml})\end{array}$ & $\begin{array}{c}\text { Quantification based on } \\
\text { concentration of genomic DNA } \\
\text { Nanogram per } \mu 1 \\
\text { (Organisms per ml) }\end{array}$ \\
\hline 1 & 2 & $29,00,000$ & Staph. aureus & $2.7 \times 10^{6}$ & $19.6\left(3.9 \times 10^{8}\right)$ \\
\hline 2 & 4 & $35,50,000$ & Staph. aureus & $3 \times 10^{6}$ & $21.7\left(4.4 \times 10^{8}\right)$ \\
\hline 3 & 5 & $5,50,000$ & E. coli & $3 \times 10^{5}$ & $7.8\left(0.8 \times 10^{8}\right)$ \\
\hline 4 & 7 & $9,50,000$ & Negative & Negative & Negative \\
\hline 5 & 10 & $39,50,000$ & Mixed & $\begin{array}{l}\text { E - } 5 \times 10^{5} \\
\text { S - } 2 \times 10^{6}\end{array}$ & $\begin{array}{l}26.2\left(2.9 \times 10^{8}\right) \\
26.2\left(5 \times 10^{8}\right)\end{array}$ \\
\hline 6 & 12 & $5,50,000$ & Negative & Negative & Negative \\
\hline 7 & 14 & $19,50,000$ & E. coli & $8 \times 10^{6}$ & $14.1\left(1.6 \times 10^{8}\right)$ \\
\hline 8 & 16 & $23,00,000$ & Staph. aureus & $3.7 \times 10^{5}$ & $17.9\left(3.6 \times 10^{8}\right)$ \\
\hline 9 & 18 & $53,50,000$ & Mixed & $\begin{array}{l}\text { E }-4 \times 10^{5} \\
\text { S }-2.3 \times 10^{6} \\
\end{array}$ & $\begin{array}{l}27.3\left(3.1 \times 10^{8}\right) \\
27.3\left(5.5 \times 10^{8}\right) \\
\end{array}$ \\
\hline 10 & 20 & $6,00,000$ & Negative & Negative & Negative \\
\hline 11 & 22 & $7,00,000$ & Negative & Negative & Negative \\
\hline 12 & 23 & $6,50,000$ & Staph. aureus & $15 \times 10^{4}$ & $11.7\left(2.37 \times 10^{8}\right)$ \\
\hline 13 & 25 & $41,00,000$ & Mixed & $\begin{array}{l}\mathrm{E}-7 \times 10^{5} \\
\mathrm{~S}-2.1 \times 10^{5}\end{array}$ & $\begin{array}{l}25.9\left(2.9 \times 10^{8}\right) \\
25.9\left(5 \times 10^{8}\right)\end{array}$ \\
\hline 14 & 27 & $50,00,000$ & E. coli & $1.3 \times 10^{6}$ & $27.5\left(3.1 \times 10^{8}\right)$ \\
\hline 15 & 28 & $9,00,000$ & Negative & Negative & Negative \\
\hline 16 & 30 & $48,00,000$ & Mixed & $\begin{array}{c}\mathrm{E}-6 \times 10^{5} \\
\mathrm{~S}-2.3 \times 10^{6} \\
\end{array}$ & $\begin{array}{l}21.6\left(2.4 \times 10^{8}\right) \\
21.6\left(4.3 \times 10^{8}\right) \\
\end{array}$ \\
\hline 17 & 31 & $39,50,000$ & E. coli & $5 \times 10^{6}$ & $20.7\left(2.3 \times 10^{8}\right)$ \\
\hline 18 & 33 & $5,00,000$ & E. coli & $6 \times 10^{5}$ & $11.8\left(1.3 \times 10^{8}\right)$ \\
\hline 19 & 36 & $22,50,000$ & Staph. aureus & $2.7 \times 10^{5}$ & $16.4\left(3.3 \times 10^{8}\right)$ \\
\hline 20 & 38 & $5,50,000$ & Negative & Negative & Negative \\
\hline 21 & 39 & $34,50,000$ & Mixed & $\begin{array}{r}\mathrm{E}-7 \times 10^{6} \\
\mathrm{~S}-1.3 \times 10^{6}\end{array}$ & $\begin{array}{l}22.9\left(2.6 \times 10^{8}\right) \\
22.9\left(4.6 \times 10^{8}\right)\end{array}$ \\
\hline 22 & 41 & $16,50,000$ & E. coli & $8 \times 10^{5}$ & $16.2\left(1.8 \times 10^{8}\right)$ \\
\hline 23 & 44 & $5,00,000$ & Negative & Negative & Negative \\
\hline 24 & 46 & $29,00,000$ & Staph. aureus & S $-6 \times 10^{5}$ & $20.3\left(4.1 \times 10^{8}\right)$ \\
\hline 25 & 48 & $16,00,000$ & Staph. aureus & S - $2 \times 10^{5}$ & $13.8\left(2.8 \times 10^{8}\right)$ \\
\hline 26 & 50 & $5,50,000$ & Negative & Negative & Negative \\
\hline 27 & 53 & $36,00,000$ & Mixed & $\begin{array}{l}\mathrm{E}-7 \times 10^{5} \\
\mathrm{~S}-2.7 \times 10^{5}\end{array}$ & $\begin{array}{l}20.5\left(2.3 \times 10^{8}\right) \\
20.5\left(4.1 \times 10^{8}\right)\end{array}$ \\
\hline 28 & 54 & $4,50,000$ & Staph. aureus & $8 \times 10^{4}$ & $7.2\left(1.4 \times 10^{8}\right)$ \\
\hline 29 & 58 & $16,50,000$ & E. coli & $5 \times 10^{6}$ & $16.7\left(1.9 \times 10^{8}\right)$ \\
\hline 30 & 61 & $6,00,000$ & Negative & Negative & Negative \\
\hline 31 & 63 & $23,00,000$ & Staph. aureus & $1.4 \times 10^{5}$ & $18.9\left(3.8 \times 10^{8}\right)$ \\
\hline 32 & 67 & $40,00,000$ & E. coli & $1 \times 10^{6}$ & $14.8\left(1.6 \times 10^{8}\right)$ \\
\hline 33 & 69 & $50,00,000$ & Mixed & $\begin{array}{l}\text { E - } 9 \times 10^{6} \\
\text { S }-2 \times 10^{6}\end{array}$ & $\begin{array}{l}27.1\left(3 \times 10^{8}\right) \\
27.1\left(5 \times 10^{8}\right) \\
\end{array}$ \\
\hline 34 & 71 & $11,50,000$ & Negative & Negative & Negative \\
\hline 35 & 73 & $7,50,000$ & E. coli & $6 \times 10^{5}$ & $12.3\left(1.4 \times 10^{8}\right)$ \\
\hline 36 & 76 & $40,00,000$ & Mixed & $\begin{array}{l}\mathrm{E}-8 \times 10^{6} \\
\mathrm{~S}-1.1 \times 10^{6}\end{array}$ & $\begin{array}{l}23.4\left(2.6 \times 10^{8}\right) \\
23.4\left(4.7 \times 10^{8}\right)\end{array}$ \\
\hline 37 & 79 & $24,00,000$ & E. coli & $7 \times 10^{5}$ & $19.3\left(2.2 \times 10^{8}\right)$ \\
\hline 38 & 83 & $7,50,000$ & Negative & Negative & Negative \\
\hline 39 & 87 & $30,00,000$ & E. coli & $8 \times 10^{6}$ & $21.7\left(2.4 \times 10^{8}\right)$ \\
\hline 40 & 90 & $23,00,000$ & E. coli & $1 \times 10^{6}$ & $19.8\left(2.2 \times 10^{8}\right)$ \\
\hline
\end{tabular}

Journal of Experimental Biology and Agricultural Sciences

http://www.jebas.org 


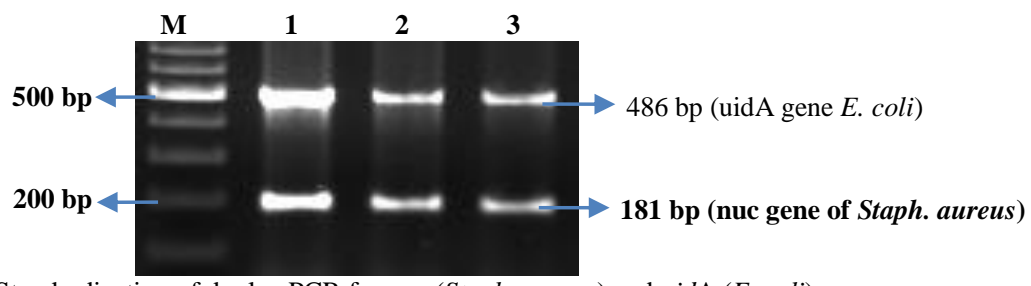

Figure 1 Standardization of duplex PCR for nuc (Staph. aureus) and uidA (E. coli) Genes (Lane M: 100 bp ladder; Lane 1 to 3: Genomic DNA of reference strains)

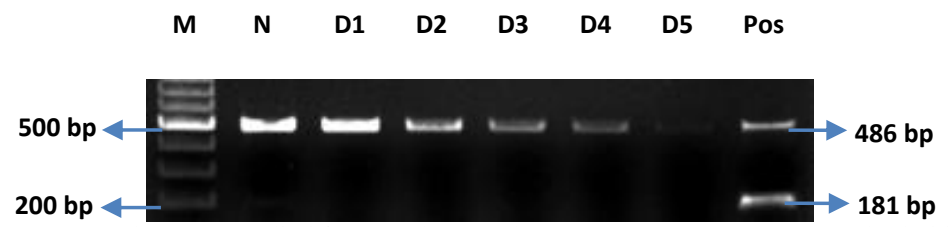

Figure 2: Duplex PCR applied for E. coli (Sample no. 31) (Here - Lane M: 100 bp ladder: Lane N: $18.92 \times 10^{6} \mathrm{CFUs} / 5 \mu \mathrm{l}$; Lane D1: $2.28 \times 10^{6} \mathrm{CFUs} / 5 \mu \mathrm{l}$; Lane D2: $0.45 \times 10^{6} \mathrm{CFUs} / 5 \mu \mathrm{l}$; Lane Pos: Positive control)

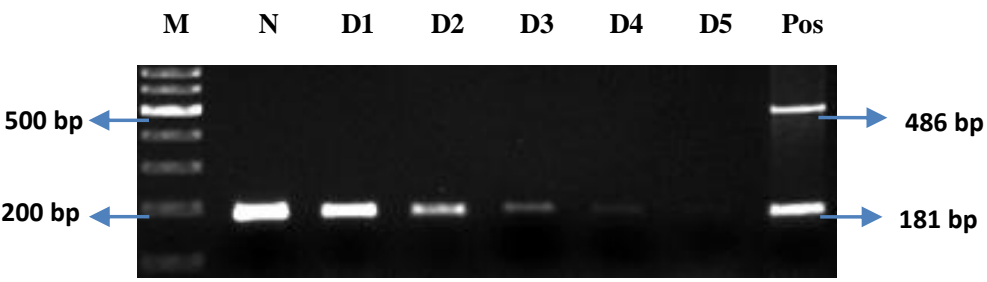

Figure 3: Duplex PCR applied for Staph. aureus (Sample no. 48) (Here - Lane M: 100 bp ladder;

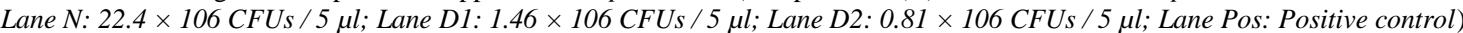

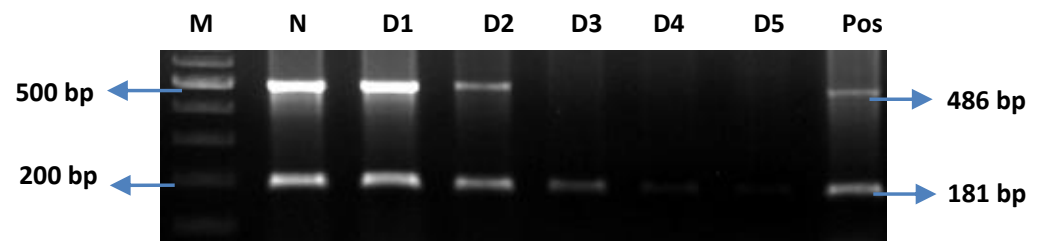

Figure 4: Duplex PCR for uidA of E. coli and nuc gene of Staph. aureus in mixed infection (Sample no. 10) (Here - Lane M: 100 bp ladder; Lane N: $E=23.9 \times 10^{6} \mathrm{CFUs} / 5 \mu \mathrm{l} ; \mathrm{S}=42.5 \times 10^{6} \mathrm{CFUs} / 5 \mu \mathrm{l}$; Lane D1: $\mathrm{E}=1.91 \times 10^{6} \mathrm{CFUs} / 5 \mu \mathrm{l} ; \mathrm{S}=3.4 \times 10^{6} \mathrm{CFUs} / 5 \mu \mathrm{l}$; Lane D2: $E=0.63 \times 10^{6} \mathrm{CFUs} / 5 \mu \mathrm{l} ; \mathrm{S}=1.13 \times 10^{6} \mathrm{CFUs} / 5 \mu \mathrm{l}$; Lane Pos: Positive control)

Journal of Experimental Biology and Agricultural Sciences http://www.jebas.org 
LOD manifold and could greatly enhance analytical sensitivity. However, tedious standardization procedures, and high cost of equipment and reagents are deterrents for its routine application in the laboratory.

Polymerase chain reaction (PCR)-based methods provide a promising option for the rapid identification of bacteria. In addition, PCR can also provide information about the load of bacteria in clinical samples. Importantly, sensitivity, specificity and the LOD can be improved by adapting PCR-based technologies. This is especially important while studying the etiology and microbial load in bacterial SCM. In this context, it is important to note that identification of bacterial species as well as the load have typically depended on culturing of the organisms involving a prior enrichment step. This overnight enrichment using non-selective media is not only likely to lead to selective growth of particular organisms due to stoichiometric competition but is also expected to lead to erroneous extrapolations of the original bacterial load due to differential growth of the various species. It is therefore important to identify and enumerate the number of bacteria directly in suspected milk sample. One of the best ways to do so is to employ PCR-based techniques.

In order to translate data from studies based on LOD of PCR for determination of bacterial load, it is important to know the number of genomic copies of the genes being targeted for amplification. While multiple copy genes are useful in increasing the analytical sensitivity and hence may be useful for qualitative assays, reducing the number of genomes would be challenging with end-point titration assays targeting genes with multiple copies, especially those with unknown or variable copy numbers among different strains. Hence, targeting a gene which is carried in known number of copies by all the members of a population is critical. We chose three genes for each of these organisms as it was possible that the LOD could be better with one than with the others (Chandrashekar et al., 2015).

In this study, we used conventional PCR assay for the quantification of Staph. aureus and E. coli in bovine subclinical masitic milk samples. For this, DNA was extracted from bacteria suspension, and the concentration in $\mathrm{ng} / \mu \mathrm{l}$ was measured, in order to calculate genome-copies / $\mathrm{mL}$ based on molarity (using Avogadro's number). The application of this method assumes that (a) a single viable bacterial cell produces a single CFU; (b) there is absolutely no loss of genomic DNA during DNA extraction procedure, (c) each cell contains only a single complement of the genome (Huggett et al., 2013). Assuming these to be true, and applying the method to a gene which exists only as a single copy per genome, the ratio of the concentration in $\mathrm{CFU} / \mathrm{mL}$ to the concentration in genome-copies / $\mathrm{mL}$ would be one.
Avogadro`s number is used to generate a standard curve by calculating the number of copy for absolute quantification of bacteria by real-time PCR. In all previous studies, absolute quantification was done by using plasmid (with the molecular weight of the plasmid and insert gene was known) (Vondrakova et al., 2014) or by using single copy gene (Karpowicz et al., 2010).

In conclusion, results with conventional PCR lay the foundation for further work on the standardization of assay with nuc and uidA genes to indirectly enumerate Staph. aureus and E. coli, respectively, directly in milk, and to correlate bacterial load with clinical or subclinical mastitis.

\section{Acknowledgement}

Authors are thankful to ICAR, Govt. of India sponsored NAIP for providing funds to conduct above research work

\section{Conflicts of interest}

No conflicts of interests are declared by authors for the contents in this manuscript.

\section{References}

Anonymous (1995a) Microbiology of food and animal feeding stuffs-horizontal method for the enumeration of coagulase positive staphylococci (Staphylococcus aureus and other species) by colony-count technique at $35^{\circ} \mathrm{C} / 37^{\circ} \mathrm{C}$. Part 1 . Technique with confirmation of colonies. International Standardization Organization document 6888-1. International Standardization Organization, Geneva, Switzerland.

Anonymous (1995b) Microbiology of food and animal feeding stuffs-horizontal method for the enumeration of coagulase positive staphylococci (Staphylococcus aureus and other species) by colony-count technique at $35^{\circ} \mathrm{C} / 37^{\circ} \mathrm{C}$. Part 2 . Technique without confirmation of colonies. International Standardization Organization document 6888-2. International Standardization Organization, Geneva, Switzerland.

Anonymous (1997) Milk and milk-based products: enumeration of coagulase positive staphylococci: colony count technique. International Dairy Federation standard 154A:1997. International Dairy Federation, Brussels, Belgium.

Ceron-Munoz M, Tonhati H, Duarte J, Oliveira J, MunozBerrocal M, Jurado-Gamez H (2002) Factors affecting somatic cell counts and their relations with milk and milk constituent yield in buffaloes. Journal of Dairy Science 85: 2885-2889.

Chandrashekar KM, Isloor S, Veeresh BH, Hegde R, Rathnamma D, Murag S, Veeregowda BM, Upendra HA, Hegde NR (2015) 
Limit of detection of genomic DNA by conventional PCR for estimating the load of Staphylococcus aureus and Escherichia coli associated with bovine mastitis. Folia Microbiologica 60: 465-72.

Chern EC, Siefring S, Paar J, Doolittle M, Haugland RA (2011) Comparison of quantitative PCR assays for Escherichia coli targeting ribosomal RNA and single copy genes. Journal of Applied Microbiology 52: 298-306.

Cremonesi P, Castiglioni B, Malferrari G, Biunno I, Vimercati C, Moroni P, Morondi S, Luzzana M (2006) Technical note: improved method for rapid DNA extraction of mastitis pathogens directly from milk. Journal of Dairy Science 89: 163-169.

Daly P, Collier T, Doyle S (2002) PCR-ELISA detection of Escherichia coli in milk. Journal of Applied Microbiology 34: 222-226.

Fang W (1996) Quantification of Staphylococcus aureus and Escherichia coli in the liquid medium by fluorimetry and its use in phagocytosis assay. Journal of Applied Bacteriology 80: 577-582.

Forsman A, Tilsal-Timisjarvi PA, Alatossava $\mathrm{T}$ (1997) Identification of Staphylococcal and Streptococcal causes of bovine mastitis using 16S-23S rRNA spacer regions. Journal of Microbiology 143: 3491-3500.

Gaibani P, Mariconti M, Bua G, Bonora S, Sassera D, Landini MP, Mulatto P, Novati S, Bandi C, Sambri V (2013) Development of a broad-range $23 \mathrm{~S}$ rDNA real-time PCR assay for the detection and quantification of pathogenic bacteria in human whole blood and plasma specimens. International Journal of Biological Medical Research 2013: 264651.

Hein I, Lehner A, Rieck P, Klein K, Brandl E, Wagner M (2001) Comparison of different approaches to quantify Staphylococcus aureus cells by real-time quantitative PCR and application of this technique for examination of cheese. Applied Environmental Microbiology 67: 3122-3126

Hegde R, Isloor S, Nithin Prabhu K, Shome BR, Rathnamma D, Suryanarayana VVS, Yatiraj S, Renuka Prasad C, Krishnaveni N, Sundareshan S, Akhila DS, Gomes AR, Hegde NR (2013) Incidence of subclinical mastitis and prevalence of major mastitis pathogens in organized farms and unorganized sectors. Indian Journal of Microbiology 53: 315-320.

Hogan JS, Gonzalez RN, Harmon RJ, Nickerson SC, Oliver SP, Pankey JW, Smith KL (1999) Laboratory handbook on bovine mastitis. National Mastitis Council, Madison, Pp.222.
Huggett J, Laver T, Tamisak S, Nixon G, O'sullivan D, Elaswarapu R (2013) Considerations for the development and application of control materials to improve metagenomic microbial community profiling. Accreditation and Quality Assurance 18: 77-83.

Jayarao BM, Gillespie BE, Oliver SP (1996) Application of randomly amplified polymorphic DNA finger printing for species identification of bacteria isolated from bovine milk. Journal of Food Protection 59: 615-620.

Karpowicz E, Novinscak A, Ba"Rlocher F, Filion M (2010) qPCR quantification and genetic characterization of Clostridium perfringens populations in biosolids composted for 2 years. Journal of Applied Microbiology 108: 571- 581.

Kim CH, Khan M, Morin DE, Hurley WL, Tripathy DN, Kehrli M, Oluoch AO, Kakoma I (2001) Optimization of the PCR for detection of Staphylococcus aureus nuc gene in bovine milk. Journal of Dairy Science 84: 74-83.

Koskinen MT, Wellenberg GJ, Sampimon OC, Holopainen J, Rothkamp A, Salmikivi L, Van Haeringen WA, Lam TJGM, Pyorala S (2010) Field comparison of real-time Polymerase Chain Reaction and bacterial culture for identification of bovine mastitis bacteria. Journal of Dairy Science 93: 5707-5715.

Meiri-Bendek, Lipkin E, Friedman A, Leitner G, Saran A, Friedman S, Kashi Y (2002) A PCR based method for the detection of Streptococcus agalactiae in milk. Journal of Dairy Science 85: 1717-172.

Birhanu M, Leta S, Mamo G, Tesfaye S (2017) Prevalence of bovine subclinical mastitis and isolation of its major causes in Bishoftu Town, Ethiopia. BMC Research Notes10:767. doi: 10.1186/s13104-017-3100-0.

Nithinprabhu K, Isloor S, Hegde R, Rathnamma D, Veeregowda BM, Murthy HNN, Shome R, Suryanarayana VVS (2013) Development of polymerase chain reaction for detection of predominant streptococcal isolates causing subclinical mastitis. Indian Journal of Biotechnology 12: 208 - 212.

Pascual MR, Calderon V (2000) Investigation y recuento de Staphylococcus aureus. In: Microbiologia Alimentaria (2nd Edn) ed. Diaz de Santos, Madrid, Spain, Pp. 77-87.

Pheuktes P, Mansell PD, Browning GF (2001) Multiplex Polymerase Chain Reaction assay for simultaneous detection of Staphylococcus aureus and Streptococcal causes of bovine mastitis. Journal of Dairy Science 84: 1140 - 1148 . 
Phuektes P, Browning GF, Anderson G, Mansell PD (2003) Multiplex polymerase chain reaction as a mastitis screening test for Staphylococcus aureus, Streptococcus agalactiae, Streptococcus dysgalactiae and Streptococcus uberis in bulk milk samples. Journal of Dairy Research 70: 149-155.

Pitkala A, Haveri M, Pyorola S, Myllys V, Buzalski HT (2004) Bovine mastitis in Finland 2001-Prevalence, distribution of bacteria, and antimicrobial resistance. Journal of Dairy Science 87: $2433-2441$.

Preethirani PL, Isloor S, Sundareshan S, Nuthanalakshmi V, Deepthikiran K, Sinha AY, Rathnamm D, Nithinpradhu K, Sharada R, Mukkur TK, Hegde NR (2015) Isolation, biochemical and molecular identification and in-vitro antimicrobial resistance patterns of bacteria isolated from Bubaline subclinical mastitis in South India. PLoS One 10: 142717.

Riffon R, Sayasith H, Khalil H, Dubreuil P, Drolet M, Legace J (2001) Development of a rapid and sensitive test for identification of major pathogens in bovine mastitis by PCR. Journal of Clinical Microbiology 39: 2584-2589.
Schukken YH, Wilson DJ, Welcome F, Garrison-Tikofsky L, Gonzalez RN (2003). Monitoring udder health and milk quality using somatic cell counts. Veterinary Research 34: 579-596.

Shome BR, Das Mitra S, Bhuvana M, Krithiga N, Velu D, Shome R, Isloor S, Barbuddhe SB, Rahman H (2011) Multiplex PCR assay for species identification of bovine mastitis pathogens. Journal of Applied Microbiology 111: 1349-1356.

Sundareshan S, Hari Babu Y, Isloor S, Awati B, Hegde NR (2012) Isolation and phenotype-based speciation of coagulasenegative staphylococci (CoNS) isolated from bovine milk samples. Frontier Journal of Animal Science 1: 34-39.

Taponen S, Salmikivi L, Simojoki L, Simojoki H, KoskinenMT, Pyorala S (2009) Real-time polymerase chain reaction-based identification of bacteria in milk samples from bovine clinical mastitis with no growth in conventional culturing. Journal of Dairy Science 92: 2610-2617

Vondrakova L, Pazlarova J, Demnerova K (2014) Detection, identification and quantification of Campylobacter jejuni, coli and lari in food matrices all at once using multiplex qPCR. Gut Pathogen 6: 12. 